street lighting by Haydn T. Harrison which brings this out clearly. The outstanding advances took place several years ago, gas and the arc lamp being two of the earliest. The invention of gas mantles largely stopped the use of luminous gas. They also prevented the adoption of the carbon filament electric lamp. The invention of the gas-filled lamp was the last notable step forward. The rapidly increasing use of electricity for street lighting at the present time is due not so much to the efficiency of these lamps as to the fact that light can be distributed from them in any required direction by simple optical means. Hence the most notable feature of modern street lighting is the large number of electric lamps fitted with reflectors or glassware designed specially for distributing the total light most efficiently. The motor vehicle head-light is an excellent example of the adaptability of the gas-filled electric lamps. These lamps only take 20 or 30 watts - the same as a small house lamp. By suitable reflections they produce a beam of light in front of the car which enables the driver to see objects to be avoided on the road 100 yards in advance. No other commercial source of light could be made to do the same thing. In modern street and road lighting, the tendency whenever there is a change of system is to raise the height of the lamps. This improves both the illumination on the road surface and the visibility, except when the weather is very foggy.

\section{Electrification of the Great India Peninsula Railway}

To a joint meoting of the Institute of Transport and the Institution of Electrical Engineers on April 28, Mr. F. Lydall read a paper giving a general account of the suburban and main line electrification of the G.I.P. Railway. He compared the actual with the anticipated traffic and dealt with the design of the plant and apparatus. The electrified portion of this railway is second only in extent, within the British Empire, to that on the Southern Railway in Great Britain. The length of single track fully equipped is $571 \mathrm{miles}$, the capacity of thesubstation plant is 100,000 kilowatts, and there are 272 miles of 100,000 -volt transmission line. It joins Bombay, a city of about $1 \frac{1}{4}$ million inhabitants, situated mainly on an island, with Northern and Central India by the North-Eastern main line and with Southern India by the South-Eastern main line. Both these lines have to negotiate the escarpment which runs roughly parallel to the coast about forty miles inland, known as the Ghats. On both sections the ruling gradient is 1 in 37 . The reason given why the traffic is less than was anticipated is the world depression of trade, which affects India in general and Bombay in particular. The most prolific source of trouble in electric operation is the propensity of the crows in and near Bombay to build nests with iron wire on the overhead line structures. It is related that one such nest was built of metal spectacleframes which had been filched by a crow from an open shop-window. During the nesting period, crows fly about with pieces of wire sometimes about a yard long in their beaks, and this naturally sometimes causes short circuits. Flying foxes also have sufficient spread of ' wing' to hook across the mains on 20,000 . volt lines. Methods to overcome these difficulties have been devised.

\section{Centre International de Synthèse}

THE "Centre International de Synthèse" of Paris is planning-and has already begun work on-three important vocabularies. The first is a vocabulary of the most important terms used by historians, jurists, sociologists, and economists. The second is a historical dictionary of science, considered in its relation to philosophy ; it will deal with the mutual influence of philosophy and science throughout the historic periods. The third is a vocabulary which will analyse the more important scientific concepts of to-day, their origin and development, and may throw some light upon the various meanings frequently assigned to the same scientific term. The Centre International de Synthèse was formed in 1925 with the object of coordinating researches in various branches of pure science. It is under the direction of M. Henri Berr, and it has among its members and associates many French and foreign savants, as well as some young and active investigators. It has four sections: (1) Synthèse historique ; (2) Histoire des Sciences; (3) Sciences de la Nature; and (4) Synthèse générale. These meet weekly, in rotation, and the results of their discussions and labours are published in two periodicals, Revue de Synthese and Archeion (Archivio di Storia della Scienza). In addition, the Centre holds yearly international meetings (semaines), during which specialists in various branches of science describe recent advances in their respective fields.

\section{Literature of Food Investigation}

WrTt the very belated appearance of the issue for September 1931 of the index to the literature of food investigation (vol. 3, No. 2, September 1931. London: H.M. Stationery Office, 1932. 2s. 6d. net), the third volume of this abstract journal is completed. It is published twice a year from the Low Temperature Research Station at Cambridge, two numbers comprising the volume. This number contains 183 pages and a list of the periodicals read. For the benefit of those who do not know this publication, it may be mentioned that it consists of elaborated titles of papers dealing with the problems of food preservation and marketing, arranged in fifteen different sections, namely, meat, pig-flesh, poultry and game, fish, eggs, dairy produce, fats and oils, fruit and vegetables, grain, crops and seeds, theory of canning, theory of freezing and chilling, bacteriology, nycology, engineering, and finally miscellaneous. It was instituted to enable research institutions in the Empire to keep abreast of progress in preservation and transport of food, but should also be of use to all who are interested in the scientific and practical aspects of this subject.

\section{The Seminoles}

Miss Frances Densmore, who has recently returned to Washington from Florida, reports a somewhat unusual attitude of aloofness towards the whites and their civilisation on the part of the Seminole Indians of the Everglades. Apparently they have never become

No. 3269, VoL. 129] 
entirely reconciled since the great Seminole wars at the beginning of the nineteenth century. Miss Densmore visited these Indians on behalf of the Smithsonian Institution, Washington, D.C., with the view of the investigation of their music, and although she had been assured that the Seminoles had no songs, she was successful, in the end, in obtaining two hundred phonograph records. In a preliminary statement issued by the Smithsonian Institution, Miss Densmore says that the Seminoles are ruled by 'old men', who remain in seclusion in the Everglades and are rarely seen. A rule is imposed upon the people that they are not to learn, or at least to speak, English. Intercourse with the whites is conducted by signs, except that sometimes they will name prices for the articles they wish to sell. They pride themselves on being a full-blood tribe, and a recent count gave 17 mixed bloods only in a population of 500 .

\section{Breeding Insects}

IN a useful note in the Vasculum for May (p. 61), Prof. J. W. Heslop Harrison gives simple instructions for the breeding of insects for experimental and other purposes. This information about the materials used, the methods of constructing cages for moths and butterflies, and the rather unorthodox methods of wintering pupæ, should help to solve problems which have baffled willing but inexpert experimenters.

\section{Announcements}

Prof. C. G. Seligman, professor of ethnology in the University of London, has been awarded the Nelson Annandale Gold Medal of the Asiatic Society of Bengal for his "contributions to the study of Anthropology in Asia ". This medal, which is awarded triennially, was founded in 1927, and the only previous recipient was Dr. Fritz Sarasin, of the Museum für Völkerkunde, Basle.

The KING, on the recommendation of the Minister of Health, has approved the appointment of Miss Ruth Darwin as a senior commissioner of the Board of Control. Miss Darwin, who is a daughter of the late Sir Horace Darwin, was an honorary commissioner in 1920-30 and has been a commissioner since Jan. 1, 1931. She is a member of the committee recently appointed to consider certain issues arising in connexion with the sterilisation of the mentally unfit.

The twenty-fifth Conference of the Society for Experimental Biology will be held at the laboratory of the Marine Biological Association, Citadel Hill, Plymouth, on July 9-11. Some thirty papers are to be read, and on July 10 a visit will be paid to the laboratories and farms at Dartington Hall, Totnes.

THE fifty-first annual meeting of the Society of Chemical Industry will be held at Nottingham on July 12-15. The presidential address will be delivered on July 13 by Prof. G. T. Morgan, on "Ourselves and Kindred Societies ". On the following day, the Messel Medal will be presented to Sir William Pope, who will give an address on "Forty Years of Stereochemistry". The greater part of the meeting will be devoted to visits to works in the neighbourhood.

Applications are invited for the following appointments, on or before the dates mentioned:- An assistant lecturer in philosophy in the University of Manchester-The Registrar, University of Manchester (June 27). A reader in electrical engineering (telegraphy and telephony) at the Imperial College, City and Guilds College-The Academic Registrar, University of London, South Kensington, S.W.7 (July 1). An assistant in the Department of Agricultural Botany of the Edinburgh and East of Scotland College of Agriculture-The Secretary, Edinburgh and East of Scotland College of Agriculture, 13 George Square, Edinburgh (July 1). A full-time master for zoology and botany at the Medway Technical College, GillinghamHead of the Senior Departments, Medway Technical College, Gillingham, Kent (July I). An assistant lecturer in pharmaceutics at the Cardiff Technical College-The Director of Education, City Hall, Cardiff (July 2). An assistant lecturer in geology in the University of Manchester-The Registrar, University, Manchester (July 2). A William Morris Research Fellow in Radiology at Mount Vernon Hospital-The Secretary of the British Empire Cancer Campaign, 12 Grosvenor Crescent, S.W.1 (July 2). A part-time lecturer in the Biology Department of the Plymouth and Devonport Technical College-The Secretary for Education, Education Office, Rowe Street, Plymouth (July 5). An Alfred Fripp Memorial Fellow in Child Psychology at Guy's Hospital-The Dean, Guy's Hospital Medical School, S.E.I (July 8). A professor of electrical engineering at the Manchester Municipal College of Technology-The Registrar, College of Technology, Manchester (July 9). A lecturer in physics and mathematics at the Sir John Cass Technical Institute-The Principal, Sir John Cass Technical Institute, Jewry Street, E.C.3 (July 9). A head of the Chemistry Department of the Sunderland Technical College-The Principal, Technical College, Sunderland (July 11). A lecturer in zoology at the Victoria University College, Wellington, New Zealand - The Secretary, Universities Bureau of the British Empire, 88A Gower Street, W.C.I (July 12). Chemists in the Department of the Government ChemistThe Government Chemist, Clement's Inn Passage, W.C.2 (July 16). A senior lecturer in economics and politics at the Rhodes University College, Grahamstown-The Secretary, Office of the High Commissioner for the Union of South Africa, 73 Strand, W.C.2 (July 30). Evening instructors in advanced building construction, sanitary engineering, and physics, at the Kingston-upon-Thames Technical College - The Principal, Technical College, Kingston-upon-Thames. An assistant master for mathematics at the Halifax Municipal Technical College--The Principal, Municipal Technical College, Halifax. A lecturer in physiology at the Chelsea Polytechnic-The Principal, Chelsea Polytechnic, Manresa Road, S.W.3. A wholetime lecturer in biology in the Department of Anatomy of the University of Durham College of Medicine-The Registrar, University of Durham College of Medicine, Newcastle-upon-Tyne.

No. 3269, VoL. 129] 